\title{
The Quiet Man and Angela's Ashes: Hollywood Representations of Irish Emigration as Male Quest Narrative
}

\author{
By Cornelis Martin Renes \\ University of Barcelona, Spain
}

Copyright (c) 2007 by Cornelis Martin Renes. This text may be archived and redistributed both in electronic form and in hard copy, provided that the author and journal are properly cited and no fee is charged for access.

\begin{abstract}
This paper analyses Alan Parker's Angela's Ashes (1999) against John Ford's seminal The Quiet Man (1952). Both Hollywood productions reflect on the Irish return myth, adapting the homonymous memoir by Frank McCourt (1996) and short story by Maurice Walsh (1933) respectively. Although Angela's Ashes reverses The Quiet Man's mythical depiction of early $20^{\text {th }}$ c. west of Ireland as rural paradise, the urban 'inferno' the former paints can be equally understood as the product of a romantic mindset which combines Irish émigré nostalgia with male quest narrative. Both views are the result of the objective each male protagonist pursues -a return to Ireland in The Quiet Man and to the USA in Angela's Ashes- and, thus, the divergence in their perception of Ireland may be explained as instances of romance in which Ireland and its culture is reduced to opposing caricatures in the service of wish-fulfilment. Not surprisingly, the criticism of capitalist, industrial America embedded in Walsh's story, masked as psychological conflict in Ford's screenplay, and the rags-to-riches American immigrant success story of McCourt's memoir were adapted to the screen with different degrees of independence from mainstream US film production. This gives additional clues on each film's use of traditional Irish imagery to the point that Ford's The Quiet Man may be understood to deliver a more emancipatory perspective on Irish identity than Parker's Angela's Ashes.
\end{abstract}

Key Words. Return myth, romance, nostalgia, masculinity, quest narrative, tradition, modernity, Irish identity.

Resumen. Este estudio compara la película Angela’s Ashes/Las Cenizas de Ángela (Alan Parker 1999) con la influyente The Quiet Man/El Hombre Tranquilo (John Ford 1952), dos producciones de Hollywood que plasman el mito de regreso a Irlanda y adaptan la autobiografía homónima de Frank McCourt (1996) y el relato corto de Maurice Walsh (1933) respectivamente. El infierno urbano que propone Angela's Ashes desmitifica el paraíso rural en que The Quiet Man convierte la Irlanda occidental de principios del siglo XX, pero igualmente se le puede considerar el producto de una voluntad romántica que combina la nostalgia del inmigrante irlandés con una narración de búsqueda masculina. Ambas visiones son el resultado del objetivo que persigue cada protagonista masculino -el retorno a Irlanda en The Quiet Man y a EEUU en Angela's Ashes- y por ello, la divergencia en sus percepciones de Irlanda se puede explicar como muestras de romance que estereotipan la identidad irlandesa en cumplimiento de deseos opuestos. No es de extrañar que la crítica a la América industrial y capitalista contenida en el relato de Walsh, encubierta como conflicto psicológico en la cinta de Ford, y la historia sobre el pobre inmigrante que hace fortuna en América descrita en la autobiografía de McCourt, hayan sido adaptadas a la pantalla con diversos grados de independencia respecto a la cinematografía comercial americana. Lo cual proporciona pistas adicionales sobre el uso del imaginario irlandés tradicional en cada película, de modo que a The Quiet Man se le puede atribuir un enfoque más critico y emancipado hacia la identidad irlandesa que a Angela's Ashes.

Palabras clave. Mito de regreso, romance, nostalgia, masculinidad, narración de búsqueda, tradición, modernidad, identidad irlandesa. 
Ever since I was a kid living in a shack near the slag heaps, my mother's told me about Innisfree and White O'Morn. Innisfree has become another word for Heaven to me (Ford 1952:13').

For over 50 years, The Quiet Man, directed in 1952 by Irish-American director John Ford on location in the west of Ireland, has been a main referent in Irish cinema, and as such still arouses plenty of critical discussion. As recently as 2001, William Dowling argued that the enduring popularity of this "romantic comedy" is rooted in its "power of cultural myth", and draws attention to its use of festive "saturnalian release", found in classical comedy (Dowling 220). Dowling's radical claim for The Quiet Man's universality by a Shakespearean reinterpretation of the film's central scene of the 'donnybrook' (a mass brawl) aims to counter the common criticism that the film is merely a simplistic distortion of rural Ireland. He locates such unfavourable views in the postcolonial discourse prevalent in contemporary Irish Studies, which denounces "cultural imperialism, with Hollywood perpetuating various Irish stereotypes whose origins lay in long centuries of English political domination” (Dowling 191).

Within the contemporary critical panorama, the prevailing academic notion is that The Quiet Man's Ireland represents “a primitive Eden, a rural idyll free from the pressures and constraints of the modern world" (Gibbons 1987: 196), which would hide the bleak Irish social reality of the inter-war period it depicts. Luke Gibbons is careful to point out that Ford left self-interrogating clues in the film that question his reconstruction of Ireland as a romantic fantasy (Gibbons 1987: 240-1), but this notwithstanding, Ford's fairy tale has become of pivotal influence for Irish film culture. Jeffrey Richards calls it "the defining Irish film" inasmuch it foregrounds the stereotypes of "violence, humour and communality" in the cinematic representation of Ireland (Richards 1997: 233). Subsequent films dealing with Ireland from the migrant's perspective, mainly produced in traditional destinations of Irish emigration such as Britain and the US, equally wrestle with the stereotypes Ford's film pioneered in foregrounding, either perpetuating or contesting them. As mainstream US film production tends to market the American immigrant
Tis the beginning for Frankie McCourt. He'll come back in a few years with a new suit and fat on his bones like any Yank and a lovely girl with eyes like pearls hangin' from his arm (Parker 1999: 120').

success story, how can its recent productions centred on Ireland be read against The Quiet Man's imagery, and how does it deal with Irish identity? A curious case is offered by Angela's Ashes, which was directed by the English director Alan Parker, produced with US and British funding in 1999, and adapted from the homonymous 1996 memoir by the firstgeneration Irish-American writer Frank McCourt. Although neither book nor film were meant as a direct response to Ford's fantasy, the similarities and differences in plot and temporal and geographical setting allow for an interesting comparison with and contestation of The Quiet Man. More specifically, the latter describes how, in the pre-Depression years of the 1920s, a first-generation Irish-American factory worker successfully accomplishes a romantic escape from the capitalist pitfalls of industrial Pittsburgh to his native Connemara in the west of Ireland, whose rural wasteland was, in fact, far from idyllic after the depopulation caused by the 1840 s potato famine. Angela's Ashes, on the other hand, depicts how a first-generation Irish-American boy and his family are forced to return to his mother's native Limerick, an industrial city on the Irish west coast, just as heavily affected by the Depression of the 1930s as the New York left behind. As both The Quiet Man and Angela's Ashes essentially deal with émigré visions of Ireland, their comparison is further justified bearing in mind that "emigration is at the centre of the Irish experience of being modern" and as such, constitutive of the Irish definition of self (Pettitt 2000: 64). Inspired by Erwin Panofski's work on the French $17^{\text {th }} \mathrm{c}$. painter Nicolas Poussin, Luke Gibbons inscribes traditional film representations of (the west of) Ireland in the strains of 'soft and hard primitivism, ${ }^{1}$.

\footnotetext{
Gibbons takes his cue on hard and soft primitivism from Erwin Panofski's essay 'Et in Arcadia Ego: Poussin and the Elegiac Tradion', published in Meaning in the Visual Arts, New Cork: Doubleday Anchor Books, 1955. Gibbons also mentions that Panofski derived this distinction from A.O. Lovejoy and G. Boas's Primitivism and Related Ideas in Antiquity, Baltimore, 1935.
} 
According to Gibbons, the pastoral romanticism of John Ford's The Quiet Man represents 'soft primitivism', which, as Panofski says, "conceives of primitive life as a golden age of plenty, innocence and happiness - in other words as civilised life purged of its vices". On the other hand, Gibbons places the pastoral realism of Robert Flaherty's 1934 documentary Man of Aran within 'hard primitivism', which, according to Panofski, "conceives of primitive life as an almost subhuman existence full of terrible hardships and devoid of all comforts - in other words, as civilised life stripped of its virtues" (Gibbons 1987: 198-200). Importantly, Gibbons claims both representations of Ireland to be products of a romantic mindset. He defines this romantic impulse as "the urge to embellish and beautify even the most disturbing and intolerable aspects of reality", which in the case of "soft" and "hard primitivism" is the elimination of "the experience of work and exploitation, the social reality of [rural] labour in the face not only of material scarcity but also profound political and economic divisions" (Gibbons 1987: 197-8). As such it creates idealisations in which "a rural world" is shown "divested of material cares and the struggle for survival” in the former strain; and "the everyday grind of work and production is desocialised and transformed into a heroic struggle between humanity and nature" in the latter (Gibbons 1987: 199, 201). Gibbons states that "due to both its colonial history and its position on the Celtic periphery of Europe, representations of Ireland over the centuries have been enclosed within a circuit of myth and romanticism" (Gibbons 1987: 194). As the object of such romantic myth-making is to make Ireland "palatable for external consumption", he warns against "a tendency to look towards Hollywood ... as the solution to cultural differences, not least those between Ireland and England" (Gibbons 1987: 241, 249).

Angela's Ashes, set in the town of Limerick in the Depression years, does not fit into the pastoralism of 'soft' or 'hard primitivism' after all, while also located in the west of Ireland, it is a very different place from Connemara- but does comment on the stereotypes of communality, violence and humour defined by Richards. Yet one may wonder whether this Hollywood production brings the viewer closer to Ireland and its culture in this description of an urban environment. The fact that Frank McCourt's book bears the subtitle "A Memoir" does not necessarily imply the historical and biographical truth of its content, which, on the other hand, is adapted with great fidelity in Alan Parker's film as Frank McCourt himself corroborates $^{2}$. Through the prism of a migrant's vision of Ireland, the male protagonists of The Quiet Man and Angela's Ashes go through the process of pursuing and achieving opposed objectives: the former escapes from the USA to Ireland, which leads to a distorted, flattering vision of the bleak rural reality of Connemara; the latter aims for the reverse, which colours the protagonist's vision of Limerick in a kind of depressing urban realism. I will argue that in Alan Parker's Angela's Ashes and John Ford's The Quiet Man a romanticising process of mythmaking of Ireland is at work with opposing end results, responding to the divergent objectives of the main characters' quests: the implementation of their escape fantasy to the countries of their dreams, the USA and Ireland respectively.

\section{The Quiet Man -An enabling return myth}

The Quiet Man was filmed on location in the small village of Cong in County Mayo, the west of Ireland, which is traditionally associated with the Romantic invention of the Celtic homeland ${ }^{3}$. The plot of the film is based on a rather bleak short story by the Irish writer Maurice Walsh from County Kerry (boardering

2 See for instance Roger Ebert's review of Alan Parker's adaptation on faithfulness and Craig Sones Cornell and Anna-Maria Petricelli's review on Frank McCourt's opinion of the film.

3 Terence Brown points out that the "main writers and thinkers [of the Irish Literary Revival] believed that a general awareness of the splendours and riches of Gaelic literary antiquity and of the residual fires of the Celtic way of life (still burning in rural districts, particularly in the West) would generate a sense of national self-worth and organic unity... (Brown 1991: 516-7). For instance, "Yeats, influenced by Romantic pastoralism, believed that the 'Celtic' ethos existed among Irish peasants and was the enduring basis for unity of Irish culture. Folk belief of the west of Ireland held a mystic appeal for Yeats... (Fleming 1995: 58). 
on Co Limerick), which was published in February 1933 in the US Saturday Evening Post. John Ford and his screenwriter Dudley Nichols adapted it including some significant changes to suit the director's objective: a festive comedy which, through a healing return of the suppressed, allows the protagonist to come to terms with the traumatic journey into the capitalist American underworld. Thus, it tells how Sean Thornton arrives in the small rural village of his parents on the Irish west coast to find some peace after dehumanizing toil in the steel mills of industrial Pittsburgh (USA) and the emotionally devastating experience of having killed a man in a prize fight ${ }^{4}$. The process of settling back into this rural community in the short period leading up to the foundation of the independent Irish Free State in 1922 (cf. Eyman 1999: 399) is surprisingly quick but not without problems: he will have to fight for the family cottage and his bride, in both cases having to confront Red Will Danaher, the local leader and richest farmer around. Two romantic symbols stand out in this bucolic Eden straight from the beginning: the idyllic vision of the white family cottage White O'Morn, shrouded in green trees and fields, and of Red Will's sister Mary Kate, the attractive red-headed Irish girl who first appears as a shepherdess. Both images are instances of the escape fantasy Sean is seeking to implement in the locality: "Ever since I was a kid living in a shack near the slag heaps, my mother's told me about Innisfree and White O'Morn. Innisfree has become another word for Heaven to me" (Ford 1952: 13 '). In order to counter the social failures of the US capitalist economy, which is tellingly blurred by Sean's personal boxing tragedy, it is the repossession of the ancestral Ireland that Sean pursues, to be reinstated as a (hu)man. Thus, Sean's return journey to Innisfree is inspired by an escape which turns into a heroic quest for integration into Irish society and a recovery of his manhood, crippled in the American capitalist 'underworld'.

\footnotetext{
${ }^{4}$ The killing in the prize fight is perhaps the most significant way in which Ford's adapts Walsh's original, which never mentions such an event as the reason for Shawn's return to Ireland. In doing so, Ford draws Sean's motivation for his journey to Innisfree into the psychological, turning it into an escape fantasy.
}

Whereas the issue of the protagonist's wealth is left indeterminate in Maurice Walsh's original, Ford's film shows Sean a wealthy man from his American adventure, so the cottage is easily achieved by simply outbidding Red Will. However, despite mutual attraction he takes longer to conquer Mary $\mathrm{Kate}^{5}$, as he is unable to mediate between the notion of love as a question of free choice, imbued by his Irish-American upbringing, and the marriage traditions of the green paradise to be recovered: Mary Kate considers receiving her dowry more than the "empty" tradition that Sean rejects. For her, it is a question of independence, honour and self-respect, whereas Sean has a well-nourished aversion of money after his American market-economy experience. The matter is aggravated by the fact that 'Trooper Thorn' (Sean's boxing name) has abdicated violence and initially refuses to fight Red Will, for which the Innisfree community seriously question his masculinity and right to marry/integrate. After a series of amusing conflicts, the issue is finally resolved in the cathartic donnybrook, a drunken village brawl through which Sean and Red Will eventually make their peace. The heroic element -or 'Homeric' as the shaugraun (matchmaker) Michaeleen repeatedly calls Sean's actions- is played out in a comic way, thus teaching Sean that fighting and drinking with one's peers is what makes the Irishman an Irish man. In Ford's film, living up to the precepts of humour, violence and drink bridges the cultural gap between the US and Ireland and allows integration into the community.

In The Quiet Man violence and drink are depicted in a light-hearted humorous way: they allow the release of underlying social tensions

5 In Walsh's story, the matter of Shawn's love affair is imbued with materialistic, unromantic undertones. Whereas Shawn is truly in love, Ellen O'Grady is not, and only agrees to marry him because she is in her early thirties and already considered rather old on the marriage market. Furthermore, the marriage is the result of scheming by her brother Big Liam, who aims to marry the wealthy widow Kathy Carey and needs the home to be empty. This plan, however, falls through and leads to Big Liam's lasting enmity towards his new brother-in-law, who he unjustly blames for the lost opportunity to acquire more money and property as well as replace his sister's hand at the home. 
and underpin the notion of harmony that permeates the village community. Thus, during and after the fight all village factions mingle and unite in a vast array of comic situations that end up questioning the reality presented. First there is the Old-IRA man who dryly comments that if the IRA were involved in his conflict with Sean, not a single stone of Red Will's house would be left standing obviously the Old IRA are not, thus eliminating the issue of political tension. Next there is the dying man who revives to join the donnybrook, showing the re-energising rather than degenerating effect of violence and drink. Then there is the large Catholic community pretending to be Protestant so that the vicar, who only serves a flock of two or three followers, may stay in the village, which effectively denies the religious strife in Irish society. And lastly there is the courting scene between Red Will and the affluent Old-English widow Tillane ${ }^{6}$, doing away with class and racial strife. Thus, Ford creates a fantasy of a harmonious, rather timeless, rural and preindustrial Ireland, in which the economic difficulties and differences of class, race, politics and religion in Irish interwar society are effectively blurred. The return-emigrant finds the ideal ground to lick his wounds from the corrupting, emasculating struggle of survival in the host country, America, and successfully negotiates the terms of (re)integration into Irish society: violence, drink and humour. In short, he becomes a(n Irish)man again, symbolically assimilating the country by marrying Mary Kate.

\section{Angela's Ashes - A disabling return reality?}

Angela's Ashes creates another vision, also from the Irish-American immigrant's perspective, but in opposition to the pastoral idyll Ford proposed some 50 years earlier.

\footnotetext{
${ }^{6}$ In Walsh's original, Kathy Carey's origins are not specified, whereas Ford introduces a colonial, class and racial theme here: Old English is a term applied to descendants of settlers from Wales, England and Normandy who arrived after the $12^{\text {th }}$ c. conquest of Ireland and slowly assimilated into Irish society, relinquishing their original power to later Protestant settlers from England.
}

Whereas The Quiet Man tells the story of an Irishman's rebirth in his home country, the title Angela's Ashes suggests precisely the contrary: the death of an Irishwoman and her home country if we follow the common stereotype of the colony ${ }^{7}$. Furthermore, "[i]f the casting of tradition in terms of maternal attachment presides over The Quiet Man, then the obverse also holds and the sacrificial death of the mother is required for progress ... This gives rise to the phenomenon of the 'Quiet Woman $^{8, ", ~(G i b b o n s ~ 2002: ~ 97) . ~ I n ~ 1935, ~ w h e n ~}$ young Frankie is only 4 years old, the McCourt family also makes the return journey from New York to Ireland, forced by the Great Depression of 1929. In contrast to Sean Thornton, who a decade earlier followed his mother's luring voice to the imaginary Innisfree, Frankie ends up in his mother Angela's native Limerick, halfway the village of Cong, where The Quiet Man was shot, and the village of Listowel, where Maurice Walsh set his story ${ }^{9}$. It shows the other side of the mythical pastoral West: the dire slum reality of a city deeply sunk into the misery generated by the Free State's stifling class, religious and political divides and the economic hardships caused by the Depression and Second World War, which The Quiet Man's Innisfree dissociates itself from. Whereas Innisfree reaches us as a problem-free, solidary, bucolic, ever-sunny, lush and green paradise, nothing could be less Edenic than Limerick: problemridden, dehumanised, poor, bleak, grim, cold and rainy, it is the Irish version of an urban 'inferno'. Thus, when Angela's husband

\footnotetext{
${ }^{7}$ In this sense, Lance Pettitt paraphrases the poet Eavan Boland, who "recognises that Ireland in the past has been figured as an essentialised female personage” (Pettitt 2000: 19).

${ }^{8}$ Luke Gibbons coins this epithet when discussing Jim Sheridan's film The Field (1990); it aptly mediates between the terms of my comparison: Angela's Ashes and The Quiet Man.

${ }^{9}$ Maurice Walsh set The Quiet Man in his home county, Kerry, in a rural area close to Listowel, 70 $\mathrm{km}$ east of Limerick, whereas John Ford significantly relocates the action to Cong, some 40 km north from his parents' native village Spiddal, in Connemara, and about $100 \mathrm{~km}$ north of Limerick.
} 
observes she could go to Hell for making blasphemous remarks, she answers him rhetorically: "Isn't that where I am, Malachy?" (Parker 1999: 56'). In consequence, Frankie only seems to survive through sheer luck, being streetwise and, above all, a wry but indispensable sense of humour:

When I look back on my childhood I wonder how I survived at all. It was, of course, a miserable childhood: the happy childhood is hardly worth your while. Worse than the ordinary miserable childhood is the miserable Irish childhood, and worse yet is the miserable Irish Catholic childhood (Parker 1999: 1', my italics ${ }^{10}$ ).

Thus, Angela's Ashes wish-fulfilment reverses The Quiet Man's; it is the story of Frankie's confrontation with a crippling, nightmarish Ireland and his quest to return to his land of dreams, America, in search of wealth and material comfort, which closely intertwines with his wish to become a man. Therefore, as the title suggests, Frank's mother remains a "Quiet Woman" -a background figure passively suffering the life meted out to her- and, perhaps contrary to expectations, it is male development that the film is concerned with.

\section{Masculinity, integration and the communal spirit}

Frankie's model in life is his father Malachy McCourt, who attempts but never manages to be an urban equivalent of the "nice, quiet, peace-loving man come to Ireland to forget his problems", as Michaeleen ironically describes Sean Thornton in The Quiet Man (Ford 1952: 21'). 'Trooper Thorn' can eventually live up to Michaeleen's words after confronting past violence through the donnybrook, in which he confirms his manhood to and integration into the Innisfree community. Malachy, however, never manages to integrate into Limerick society, and, in an intertextual twist, Michaeleen's words acquire a bitter echo in the poem "The Man from the North", which Angela dedicates to her husband in Frank McCourt's memoir:

\footnotetext{
10 The film lifts this quote verbatim from the beginning of McCourt's memoir (1997: 9).
}

Oh, Garryowen may be more gay

Than this quiet man from beside Lough Neagh

And I know that the sun shines softly down

On the river that runs through my native town.

But there's not - and I say it with joy and with pride

A better man in all Munster wide

And Limerick town has no happier hearth

Than mine has been with my man from the North.

I wish in Limerick they only knew

The kind kind neighbours I came unto.

Small hate or scorn would there ever be

Between the South and the North Country

(McCourt 1997: 164, my italics)

Here irony is served from a much grimmer and painful perspective, which explains the hysterics Frank's mother goes into when she recites its final stanzas. Although a great storyteller -a talent Frankie inherits- Malachy is, of course, a hopeless failure as a father and man, partly due to a serious drinking habit which does not allow him to hold a job for long.

However, where the plot of Ford's film pivots on a notion of individual failure and touches upon the industrial misery of Pittsburg only subliminally, Angela's Ashes clarifies that Malachy's alcoholism is not only caused by the economic hardships of the working class (here aggravated by the Depression and WWII years) but also worsened by the religious and political divides in the Irish Free State (192237, later Éire and as of 1949 the Republic of Ireland). These are issues that The Quiet Man glosses over. Although Malachy desperately tries to undo his outcast status by respecting a minimum decorum in dress, he is the constant victim of rejection and bigotry, which belie the idyllic lines of the poem above. When he applies for work and financial help, he achieves little or none on account of being Northern Irish and hence suspect of being a Presbyterian and Orange supporter. Nothing is more beside the truth as he fought for the Old IRA (active in the period 1919-23) and was made to flee to the USA because of his involvement (precisely when Sean settles back into Innisfree), but prejudice is repeatedly and insistently used against him and crushes any future prospects. Tellingly, his Republican past is most clearly revealed whenever he is drunk, singing songs of resistance against English 
domination, such as 'Roddy McCorley' and 'Kevin Barry', and exhorting his children to die for a free, Catholic Ireland. In these less quiet, loquacious moments of drinking, a serious reason for his alcohol abuse may be detected: the tragic condition of being a partisan and suspect of the contrary.

Prejudice did not play an important role in Brooklyn, where a vast, mixed immigrant population was equally affected by the misery of the Great Depression of the 1930s; however, Angela's family and the Limerick community insistently blame her troubles on marrying a man from the North and so elude helping her. This is in stark contrast with The Quiet Man's harmonious communal spirit, which -as Scott Eyman points out- seeks to support 'the Yank' in his quest for integration throughout the film (Eyman 1999: 409). Community sympathies are generally with Sean and even result in different village factions plotting to his favour against Red Will, the local strong man and bully. However, in lack of community support Malachy is forced to take the only road befitting the eternal outcast: he disappears from Limerick to work in the factories of wartime England, drinking his gains and leaving the family destitute. The sense of individual and collective failure is acutely reflected in Frankie's observation that "If I lived in America I could say to my father, 'I love you, Dad', like in the movies, but in Limerick I can't ... Here it means being a sissy" (Parker 1999: 88'). It is evident that, due to his presumed political and religious difference, in Eire "quiet”/silenced Malachy can never accomplish what a man is supposed to do: provide for his family. As the oldest boy it is Frankie's obligation to try at his dad's failing. From the moment of his father's disappearance, Frankie entertains the wish to become the pillar of the family economy, taking up all sorts of menial jobs to help his family, which barely subsists on the benefits of meagre local charity.

\section{Masculinity, integration, violence and drink.}

Violence is the cathartic catalyst allowing the Innisfree community to release tension and establish peace, and therefore depicted as a healthy force of integration. This is what Sean learns and it contrasts to the only scene of harmful violence in The Quiet Man, which is significantly set in America and deals with Sean's fatal blow to his opponent in the prize fight (Ford 1952: 71'). Violence is also inextricably linked to drinking, which is used to "seal bargains, to cement friendships, to welcome visitors and friends" (Richards 1997: 235-6). None of this holds true in Angela's Ashes: in Malachy's pub fights violence forms a destructive binary with alcohol, leading to loss of work and community support. Furthermore, violence affects Frankie directly to highlight his difference, being blamed for being poor, Irish-American or Northern-Irish.

Whereas the living conditions in Innisfree are problem-free and bucolic, the McCourt family is crushed by the harsh, oppressive environment of Limerick's Depression and WWII years. Tellingly, the film opens with a bleak and rainy image of Barrack Hill street in the Limerick slums, where Frankie spends most of his youth in a smelly derelict terraced house. Its wet, inhospitable ground floor is aptly nicknamed 'Ireland' and its dry top floor is coined 'Italy', the latter a paradisiacal escape fantasy from the urban 'inferno' the McCourts are confined to. In this dehumanising situation poverty is stifling (charity is less than making up for unemployment), death and disease are omnipresent (while his twin brothers die of starvation, Frankie ends up in hospital with typhus), and class, religion and politics are the markers of the underprivileged (Frankie is rudely refused as an altar boy on class grounds, and the IRA representative refuses to help Malachy financially). Rather than offering a release from tension, solving conflict and reinstating a sense of community, violence and drink permeate Limerick society in emasculating, crippling and insolidary ways, as is ultimately shown in Malachy's disappearance from the narrative.

\section{Masculinity, integration and humour.}

If in The Quiet Man humour obscures its tragic undertones ${ }^{11}$ and highly favours a

\footnotetext{
${ }^{11}$ Luke Gibbons states in this respect that "[f]or all its romanticism, death is never far from the surface, giving even comedy itself a macabre touch. The sudden intrusion of death into the levity of the wedding celebrations in The Quiet Man -the frightening flashback follows as a stark contrast to a rollicking performance of "The Humour Is On Me Now'- shatters Sean's idyll of home...” (2002: 67).
} 
comic plot structure, in Angela's Ashes it also takes the dramatic edge off Frank's "miserable Irish Catholic childhood" up to the point of questioning the qualification as such -"the happy childhood", after all, "is hardly worth you while" (Parker 1999: 1'). Much of it is created through Frank's child's perspective on his dire living circumstances. His streetwise attitude adds to the humorous situations and interpretations, which allow him to survive and get on. Humour also serves to criticise and make this 'Misery Memoir' palatable to the audience (National Review, 26 Oct. 1998) and takes issue with religion, class and poverty. Frankie explains, for instance, that people in Limerick, "the holiest place in Ireland", go to church not because they are devout, but rather so as to find some warmth and comfort against the cold and rain of the city (Parker 1999: 68'), and he also makes sure to confess to a deaf ninety-year-old priest who sleeps in the confession box, so that he may be easily absolved for the sin of masturbation (Parker 1999: 97’). Moreover, humour is vital to ready the viewer for the presentation of a grimmer and tougher side of Frankie. When he starts working for the local money-lender who has half of Limerick in her grip, Frankie shows a willingness to go against his own kind in order to enable his return to America. Initially he is shown to follow the harsh, insolidary precepts of market-economy individualism (ironically also at the heart of US capitalism, the subliminal issue of The Quiet Man), but his phrasing of letters to the poor makes for a benevolent smile. His collaboration in usury is finally undone when he destroys Mrs. Finucane's accounting books at her death. Humour equally underpins Angela's Ashes' plot, but in contrast to The Quiet Man it serves to debunk an idyllic view of Irish (inter)war society, to make drama palatable through comic inscription, and last but not least, to underpin young Frankie's manhood; thus, humour becomes an expression of his strength of survival, toughness and resilience in the face of adversity, and, as such, of vital importance in the development of his quest for integration.

\section{Masculinity and integration in pastoral and urban quest narratives.}

If Dowling describes The Quiet Man as a powerful modern myth, a tale with deep explanatory and symbolic resonances for Irish (film) culture, then Angela's Ashe s may be seen to demythologise its defining elements of communality, violence and humour. However, Angela's Ashes only does so by inscribing itself into an opposing myth: "the miserable Irish Catholic childhood”, which eventually forces Frank to leave the country. Sean reaches the bucolic paradise of Innisfree after a dehumanizing journey through the industrial 'hell' of the American capitalist economy, in which the old family home, the donnybrook and his marriage symbolically oppose themselves to the shack near the slagheaps of the Pittsburgh steel mills, the killing of his opponent in a prize fight and his solitariness. Similarly, Frankie's return to Limerick is marked by the suffering effigy of his patron Saint Francis, protector of the poor, and the image of the well-to-do but terminally-ill Theresa Carmody. Yet, these symbols do not signify Frankie's final destination but rather mark the path of his quest through an Irish 'underworld': a townscape stricken by poverty, unemployment, hunger, alcoholism, violence, insolidarity, the political strife caused by long years of British domination and the concomitant religious divide between Catholics and Protestants.

Whereas Sean soon manages to inhabit the Irish land, represented by the idyllic family cottage White O'Morn, the welcoming Innisfree community and the nubile, attractive Mary Kate Danaher, such a symbolic possession of Ireland is forever denied to young Frankie. The Barrack Hill dwelling is nothing more than a derelict uninhabitable shed as the name of the street itself indicates, solidarity is inexistent, and his one and only girlfriend, the middle-class-born Theresa Carmody, dies of tuberculosis in adolescence, all of which signals the impossibility of Frank's integration on Irish soil. The hapless Depression years in Limerick (extended into the economic hardships of the Second World War) and the Irish political and religious situation force Frankie to project salvation elsewhere. It takes him 13 long, troubled years to exchange the Barrack Hill dwelling for his Land of Opportunities, the USA, symbolised in the film by the Statue of Liberty, which beckons at the end of a road full of trials and tribulations. Significantly, the Statue of Liberty is shown to merge with Frankie's patron saint's image, the sexual connotations of which are rife: only Frank's arrival in America fulfils his strong wish of integration, in which the leaving 
behind of economic, political and religious problems aligns with his becoming a man.

This rejection by Irish society matches the development of the theme of masculinity and integration in The Quiet Man to the extent that 'Trooper Thorn' is initially unwilling to fight, a reluctance the Innisfree community has difficulties understanding and interprets as both a lack of manhood and belonging. Similarly, in Frank McCourt's memoir a doctor exhorts Frankie, who is hospitalised with typhus, to "be a man, be a good trooper"12. (McCourt 1997: 284, my italics). The illness that ails Frankie metaphorically, prevents him from being "a good trooper" and his father also suffered, is the impossibility of integration, of becoming a(n Irish)man on native soil, a problem which Sean Thornton also struggles with but overcomes; through a humorous engagement with fight and drink he successfully negotiates the economic, political and religious pitfalls of Irish society. However, Frankie only undertakes the full passage to manhood upon his arrival in America: by then he is of a mature age (18), successful with women, studies and work, and establishes a family. Sean, on the other hand, recovers his manhood in the cathartic donnybrook, thus being allowed to take his place in Irish society. Not surprisingly then, each film develops the return myth to Ireland in opposing quests: Sean leaves Ireland as a young boy and, come into fortune but emotionally emasculated by the American experience, returns to the motherland in order to recover his manhood and a place in society, whereas these terms are reversed in Frankie's quest. Due to his family's hapless return to Limerick, Frankie's childhood and teenage years are set in Ireland, the miseries of which can only be undone by recovering an idyllic America, synonym of his integration into society and manhood ${ }^{13}$.

\footnotetext{
${ }^{12}$ Originally restricted to soldiers of the cavalry, the qualification 'trooper' has become a general, colloquial reference to any kind of soldier regardless of rank. It is also used as a common reference to any man displaying strength of character and purpose in the face of adversity, under influence of a misspelling of the expression 'real trouper' (cf. The Oxford Dictionary of American Usage and Style, 2000).
}

The articulation of integration and masculinity has an oral component, as behoves story-telling; Malachy is effectively turned into a 'quiet man' and silenced in the mother country, whereas Frankie only finds his voice on reaching America, as his memoir and its sequels so successfully testify. But obviously, their articulation is also physically transcribed into memoir and film. As an adolescent, Frankie discovers his sexuality, but feelings of guilt induced by religious precepts prevent its exploration - at least, in an urban environment. Precisely one of the rare instances of rural Ireland in the film shows Frankie with a certain amount of sexual freedom: he and three friends masturbate while watching a flock of sheep (Parker 1999: 100'). This stark yet humorous scene contrasts with Sean's enabling vision of Mary Kate amongst her sheep, which reroutes desire from the animals to the woman, whose availability and interest is highlighted in greenery and soft romantic light (Ford 1952: 8'). McCourt's memoir underscores this contrast in a scene that the film suppresses: Frankie climbs an old watchtower in the fields near Limerick, entertains a fantasy of himself as the object of desire of staring milkmaids, and: "in full view of Ireland I interfere with myself and spurt all over Carrigogunnell ${ }^{14}$ and

13 Interestingly, Maurice Walsh's original sees Shawn Kelvin leave for America at the age of 20, more or less Frankie's, and return to Ireland 15 years later, more or less Sean's age when he arrives in Innisfree. Simply fed up with the hard toil in industrial USA, Shawn's perception of Ireland must have been a bit more realistic than Sean's upon his return, which is shown in his unwillingness to antagonise Big Liam, the richest farmer around and at the centre of local power.

${ }^{14}$ The ruins of Clarigogunnell castle are about $8 \mathrm{~km}$ west from Limerick, just outside the village of Clarina. The original stronghold belonged to preNorman, Celtic lords, as one Irish translation of its name, Carraig Ó gConaing or 'The Rock of the $\mathrm{O}$ Conaings', indicates but a castle was raised on the location by the Norman invaders. It passed back to Irish hands but was finally blown up in 1691 by William of Orange's supporters to prevent it from serving as a fortress for Irish attacks against English domination ever again (Tobin and O’Connor 19912005). The history of the castle's destruction caused by the British domination of the Irish draws the masculinity issue depicted in the film scene into the political. 
the fields beyond. That's a sin I could never tell a priest" (McCourt 1997: 376). The tower in ruins, the 'seeding' of the land, the physical absence of women and the religious guilt complex express a frustrated phallic symbolism that underscores how his wish to possess the female body and integrate into Ireland unsuccessfully merge. What is more, on meeting the red-haired green-eyed adolescent Theresa Carmody, manhood and integration still remain out of reach. Both book and film depict his first sexual intercourse, but significantly, his loss of virginity is linked to death and therefore crippling: the relationship cannot prosper due to Theresa's terminal illness. In contrast to the pastoral Mary Kate, who signifies the invigorating Ireland Sean manages to inhabit, Theresa's untimely demise of tuberculosis evokes a doomed, hostile and emasculating Irish society that offers no prospects to Frankie.

If Frank's arrival in the USA in 1949 is symbolised by the sunlit image of the Statue of Liberty and contrasts with the lunar eclipse on the eve of his departure from Ireland (Parker 1999: 130-4'), the memoir depicts this event as sexual conquest. After his ship has moored in New York, Frank has sexual intercourse with an American girl. As the 18-year-old enters the woman, his mind is forced back to his dead girlfriend, crying out to her in his thoughts, "oh God oh Theresa, do you see what is happening to me at long last?" This time, the sexual union is not desperate but enabling and invigorating, thus denoting the final reckoning with his Irish past and the confirmation of America as "a great country” (McCourt 1997: 457-60). Frank's entering the Hudson, gateway to the States, matches his penetration of the female body, and, thus, his (re)integration into America is first and foremost shown as a rite of passage into manhood. The successful completion of this ritual foreshadows the fulfilment of Uncle $\mathrm{Pa}$ 's prediction on beholding the lunar eclipse. At Aunt Aggie's claim that the eclipse is a bad omen, a sign of "the end of the world", her husband replies that "Tis the beginning for Frankie McCourt. He'll come back in a few years with a new suit and fat on his bones like any Yank and a lovely girl with eyes like pearls hangin' from his arm" (Parker 1999: 120'). Whereas the latter scene links the Irish female again to a notion of doom, signifying the book and film title's premonitory end of Mother Ireland for Frankie, it fastens hope and strength onto the Irish male. The film version delivers the penetration scene as a (perhaps prudish) metaphor: the bow of the ship - a rather phallic Irish Oak- cleaves the waters of the river Hudson towards the Statue of Liberty. This liberating union of the male and female principle was already foreshadowed in the merging of Saint Francis' and the Statue's image, which imbued Frankie's suffering with hope back in Ireland (Parker 1999: 68').

The contrived use of symbols in Frank McCourt's story shows that Angela's Ashes' vision of Ireland and America is yet another instance of romance, although in terms opposing The Quiet Man's (cf. Gibbons 2002: 103). The former reverses the latter's nostalgic portrayal of a Romantic, enabling rural Ireland to a Realist, disabling urban one, and counters "the miserable Irish Catholic childhood" with the post-war American Dream, obscuring the earlier problems of survival for Frankie's family in the Brooklyn of the Depression years. Angela's Ashes offers yet another way of representing Ireland: feelings of nostalgia embellish past misery to recreate Ireland as the bumpy road in a male quest narrative whose destination lies elsewhere. This tale of male wish-fulfilment cleverly readies Irishness for American consumption by selling a stereotypical message of Irish misery and resilience softened by humour and blarney, narrating why the Irish left their homeland and how they survived in the face of adversities, and in doing so it reconfirms the myth of Irish immigration as a success story. One of Angela's Ashes' many positive appraisals in the US press runs significantly as follows: "But as many Irish seem to thrive on their misery, McCourt manages to deliver an irreverent, humorous tale of his daily struggle to survive and to get back to his birthplace, America” (Saah 1990-2001).

It should therefore come as no surprise that McCourt's memoir was a bestseller in the USA as it reproduced the American rags-to-richess story of immigrant success. While it was awarded the 1996 National Book Critics Circle Award and the 1997 Pulitzer Prize, both in the category biography, critical reception in Ireland was less favourable, pointing out the book's novelistic distortions. The late Limerick-born actor Richard Harris, for 
instance, takes issue with McCourt's "bitter attack on his native city”, (Phelan 2000) and a newspaper article suggests that Alan Parker's film actually boosted the controversy:

Accusations that Frank McCourt had exaggerated the poverty he had suffered during his Catholic Irish upbringing were further fuelled by Parker's adaptation of Angela's Ashes in 1999. According to journalist Fergal Keane $^{15}$, 'Parker went so far over the top that I ended up feeling cheated. The film led us on a rainy dance through every Irish cliché'. (McGlone 2003).

Significantly, Richard Harris criticizes Alan Parker for having "dated [the city] back to the late 19th Century. It is more Dickensian in its squalor than it is accurately Limerick" (Phelan 2000). Therefore, considering Angela's Ashes a truthful and realistic account, as the qualifications 'memoir' and 'biography' might suggest, is at odds with a delivery of Ireland that, like The Quiet Man's, responds more to the internal requirements of romance than an accurate description of reality. One might, therefore, elaborate on the distinction between 'hard' and 'soft primitivism ${ }^{16}$ ' and propose a strain of romantic portrayal for Angela's Ashes that could be denominated 'hard urbanism'. Adapting Panofski's definition, this would conceive of urban life as almost subhuman existence full of terrible hardships and devoid of all comforts -in other words, as civilised life stripped of its virtues- while beautifying the suffering it causes. This interpretation would see Angela's Ashes as a realist quest plot against a stark industrial townscape rather than natural landscape, a formidable 'Dickensian' enemy of adverse metropolitan livingcircumstances which lays out a series of tests alcoholism, unemployment, poverty, deficient housing and hygiene, disease, death, insolidarity, lack of community tissue, economic, religious and political divides ${ }^{17}-$ the protagonist has to over-come in order to

\footnotetext{
${ }^{15}$ Fergal Keane is a Special Correspondent for BBC News. He was born in London in 1961, brought up in Ireland, and educated in Dublin and Cork. He began his career in journalism in 1979 as a reporter on the Limerick Leader and Chronicle, and was a BBC correspondent for Northern Ireland.

${ }^{16}$ See the second and third page of this paper and, by extension, Gibbons 1987: 197-201.
}

achieve his object of desire. Rather than obviating actual socio-economic conditions, Angela's Ashes' urban realism highlights them to test and toughen up the young hero on his road to manhood/a new home/a better life. It is, logically, the Old Mother Ireland Frankie has to write off -hence the title- and the Promised Land of America he has to inscribe himself into so as to develop as an Irish-(A)m(eric)an and take his place in a society that allows him to overcome the troubles encountered back in Ireland. Angela's Ashes and The Quiet Man have sold so well to the American audience -a nation of immigrants- because both migrant stories conjoin nostalgia and humour in a marked capacity for survival. However, The Quiet Man barely touches upon the crippling capitalism of industrial Pittsburgh in order to facilitate the resolution of Sean's search for recovery and integration in a 'soft-primitivist' vision of the west of Ireland, while Angela's Ashes paints an elaborate 'hard-urbanist' picture of the Irish West so as to project the fulfilment of Frank's quest into the American Dream.

\section{Hollywood and the Irish emigration experience.}

The difference in the voicing of the emigrant experience in The Quiet Man and Angela's Ashes bears obvious links to the personal biographies of John Ford and Frank McCourt. The former was the son of immigrants to the USA, and although his upbringing was imbued with love for the old mother country and its culture, and probably further enhanced by the excesses and disorders of the American market economy that lead to the hardships of the Great Depression, he would never live there. Thus, fictional Sean (not surprisingly his name is Irish for John) implements a return journey which parallels John Ford's 'homecoming to Ireland' to recreate his Irish Dream (Dowling 2001: 196) -a sweet, enabling picture of Connemara as passed on by his parents ${ }^{18}$ and

\footnotetext{
17 Lance Pettitt speaks of the "the considerable economic, social and cultural difficulties that beset the southern state: limited economic power, high unemployment, poor social welfare provisions, social conservatism and, above all, cultural insularity" in the period between 1932 and 1959 (Pettitt 2000: 7).

18 See endnote 9.
} 
enhanced by his imagination into what has been termed "a product of [his] émigré nostalgia” (Pettitt 2000: 64).

Frank McCourt was also born in the USA but, unlike John Ford, spent most of his childhood in Ireland. Its harsh living conditions in the Depression years and the Second World War fuelled his desire to settle back in the United States, where he would successfully reestablish himself. The latter he had only known in dire circumstances at a very early age, but its image was embellished by schoolmasters' tales, a child's optimism and (not surprisingly) Hollywood movies at the local Limerick cinema. Through the distorting lens of time, memory and physical distance, Frank recreates a tough, disabling Ireland ${ }^{19}$ that feeds back into the safe American H(e)aven and makes for an equally nostalgic vision or beautification of past hardships: "McCourt may have had a miserable childhood, but he would not trade it in for another - or at least would not have missed the parts he retails in his memories" (Ebert 2000). An analysis of the immense popularity of McCourt's novel in the USA ironically states that in this "cynical" age:

Our infatuation with all things Irish is a hopeful sign in post-modern America. Rumors that the Irish Republic has considered changing its name to 'Frank McCourt' are without foundation. Yet in the present craze for everything Irish, not least Mr. McCourt's memoir-turned-cottage-industry, Angela's Ashes, something odd is going on. ... As we picture them, the Irish are a pre-civilized, or rather a pre-modern, people. And nowadays, the distinction between modern and premodern can be crystallized in a word: passion (National Review, 26 Oct. 1998).

And thus, observing that "[n]aturally Hollywood has cashed in on the phenomenon", it articulates the reasons for the book's rapid and faithful reproduction onto the screen, financed by the English-born director Alan Parker and the Hollywood-based producers Scott Rudin and David Brown for Paramount and Universal Studios.

In the light of the above, the imagery of The Quiet Man and Angela's Ashes comes forward as essentially compatible. Their humour and

\footnotetext{
${ }^{19}$ See Jim Saah's interview with Frank McCourt for comments on this fictionalising process.
}

irony play on the gap between fantasy and reality, undermining the exclusive terms of the west of Ireland as 'Rural Paradise' or 'Urban Hell', and foregrounding a nostalgic vein in both films that feeds on traditional, pre-modern images of Old Europe, seen through the prism of America and projected onto Ireland. If the emigration phenomenon is indeed central to Irish modernity, then Hollywood productions such as The Quiet Man and Angela's Ashes seem to share a rather reductive definition of Irishness, at odds with Fintan O'Toole's expansive, postmodern view in which physical adaptability and mental mutability is the Irish answer to the "permanent impermanence" of emigration (quoted in Pettitt 2000: 22). Thus it would appear that, in mediating cultural difference between Ireland and the USA, both The Quiet Man and Angela's Ashes re-affirm romantic visions of Ireland and mythologize the emigration experience into self-affirming male quests for integration so as to suit an audience both American and abroad, in line with the prevailing demands of the Hollywood canon. Not surprisingly, Ford's The Quiet Man has been described as "a Western made in Ireland” (Pettitt 2000: 66) and Parker's Angela's Ashes as a "testimony to the fortitude of the human spirit under even the worst circumstances” (Berardinelli 1999).

Yet, while the Hollywood film industry's financing, marketing and powerful demand for profit do condition cinematic end result, their effects are not uniform, depending on a film's integration in its production structures. And this calls attention to the particular embedding of traditional representations of Irishness within the discourse of both films. Or, to put the issue in a different way, the problem with the use of stereotypes "is not that they are untrue, but that they are portrayed as the norm" (Gibbons 2002: 96). Precisely John Ford encountered tremendous, long-lasting obstacles when trying to raise Hollywood funds for his film as it "was seen as having no commercial potential" (Dowling 2001: 192), whereas the opposite was true for Angela's Ashes, no doubt provoked by the proposal of an Irish homecoming in the former against an American homecoming in the latter. Or, as RKO distribution head Ned Depinet told Ford upon reading The Quiet Man's screenplay: "You're in Ireland and we're in America, and I'm not going to pay for that" (quoted in 
Eyman 1999: 327), so that Ford had to find ways of making his project palatable for the film industry. Thus, what Lance Pettitt calls "astute critics of popular culture" nowadays agree that Ford's play with stereotypical comic and idyllic exaggerations and socio-economic omissions in The Quiet Man was meant, more than to please the studio system, to include "a reflexive critique of Irish film representation" (Pettitt 2000: 65-6). Whereas William Dowling embeds such a critique of traditional Hollywood representations of Ireland and Irishness within a sophisticated discussion of artistic independence -Ford's struggle for "artistic integrity" against "Hollywood greed" (2001: 195)- Luke Gibbons sees it as the direct result of Ford's social criticism of the dark side of "the American way of life", that is, "the ruthless pursuit of profit and money at the expense of all other human and moral considerations" (Gibbons 2002: 70). However, the same cannot be said for Alan Parker's Angela's Ashes, which does not maintain such a critical distance towards the projection of Irish and American culture through the Hollywood prism. This is not surprising as Angela's Ashes' homecoming is precisely materialized in America and therefore confirms the American Dream, which paved the way for a quick Hollywood adaptation to the screen. Furthermore, the wry humour permeating Frank McCourt's memoir offers a selfreflexive counterpoint to its description of a "miserable" Ireland, but is given less prominence in the film, in which imagery and voice-in-off only partially manage to replace the novel's ironic narrative voice (Ebert 2000). Thus, the critical reception of Parker's Angela's Ashes was less favourable in Ireland, while it received more positive reviews in the USA.

As a Hollywood depiction of the west of Ireland, The Quiet Man's myth-making has also been contested in Ireland, but Angela's Ashes commits the additional 'sin' of creating an escape fantasy that, according to Luke Gibbons, "simply reverses The Quiet Man by looking to America as the answer to Ireland's ills”. However, in The Quiet Man:

... Ford is intent on questioning not only an unthinking adherence to one's own diasporic inheritance, but to the dominant values of the host American culture, and what is required to survive in it. Sean Thornton's engagement with the moral economy of rural Ireland allows him to break from the impasse of unfettered American individualism, according to which all value is subordinated to private gain, market relations and forms of competition whose ultimate logic is violence. Though Sean Thornton stays in Innisfree with Mary Kate, Ford seemed to bring this deeply critical stance towards American values back with him to the United States ... Ford's life and work may be seen as an attempt to retrieve the American dream by transferring its sympathies from White, European legacies of colonial expansion to the rights of other cultures and indigenous peoples considered to be mere obstacles to progress, and his Irishness was central to this task (Gibbons 2002: 103-4).

And through an Irish-American, and what we would now call postcolonial commitment with modernity, Ford's The Quiet Man goes beyond "an introverted ethnicity" (Gibbons 2002: 15) that merely confirms a stereotypical return to tradition to remedy America's ills. Sean's American trauma -his unintended killing of a man in return for some prize fight cash- may only be solved when he has successfully renegotiated not only the shortcomings of American society, as argued above, but also of Irish tradition, "especially as it affects the subjugation of women" (Gibbons 2002: 18). On the one hand, Sean eventually decides to accept Mary Kate's dowry in respect of her honour and economic independence, but he and his wife later challenge Irish custom by destroying this "dirty money", which leads to the cathartic, communal re-inscription of the American prize fight: the donnybrook (Gibbons 2002: 55). On the other hand, the couple express their engagement with female empowerment when Mary Kate, with Sean's approval, casts away the stick rebellious Irish women were traditionally punished with (Gibbons 2002: 18). Seen from this perspective of transformative potential in which gender is the focus of attention, Ford's version of male quest narrative has therefore retained a greater independence of spirit and offers a more dynamic engagement with Irish modernity than Parker's Angela's Ashes, which surely lies at the basis of the interest The Quiet Man still arouses. 


\section{Works Cited:}

Berardinelli, James. 1999. “Angela’s Ashes” (film review). Reelviews.net. http://www.reelviews.net/movies/a/angelas.html Access: November 2006. http://movie-reviews.colossus.net/ movies/a/angelas.html Access: 9 Apr. 2004.

Brown, Terence (ed.). 1991. “Cultural Nationalism 1880-1920”. Seamus Deane (ed.). The Field Day Anthology of Irish Writing. Derry: Field Day Publs. Vol II.

Cornell, Craig Sones \& Anna-Maria Petricelli. 1999. “Angela’s Ashes” (film review). CinemaSense.Com. http://www.cinemasense.com/Reviews/angelas_ashes.htm Access: 5 November 2006.

Dowling, William C.. 2001 (Fall-Winter). “John Ford's festive comedy: Ireland imagined in The Quiet Man”. Eire-Ireland: Journal of Irish Studies. 190-211. FindArticles.com. http://www.findarticles.com/p/articles/mi_m0FKX/is_2001_Fall-Winter/ai_83447255 Access: November 2006

Ebert, Roger. 2000 “Angela’s Ashes” (film review). Chicago Sun-Times. 21 January. http://rogerebert.suntimes.com/apps/pbcs.dll/article?AID=/20000121/REVIEWS/1210302/1023 Access: November 2006

Eyman, Scott. 1999. Print the Legend: The Life and Times of John Ford. New York: Simon \& Schuster.

Fleming, Deborah. 1995. The Irish Peasant in the Work of W. B. Yeats and J. M. Synge. Michigan: U. of Michigan Press.

Ford, John. 1952. The Quiet Man. Producer Herbert J. Yates. Hollywood USA: Republic film studios.

Gibbons, Luke. 1987. "Romanticism, Realism and Irish Cinema”. Cinema and Ireland. Eds. Kevin Rocket, Luke Gibbons and John Hill. New York: Syracuse University Press. 194-257. . 2002. The Quiet Man. Cork: Cork University Press.

McCourt, Frank. 1997 (1996). Angela’s Ashes. New York: Touchstone.

McGlone, Jackie. 2003. 'Kiss and tell with a sucker punch.’ Scotsman on Sunday, 26 October. http://news.scotsman.com/features.cfm?id=1178732003 Access: November 2006

National Review magazine. 1998. "Fighting Irish (Author Frank McCourt's memoir has helped spur an increase in the popularity of all things I rish)". New York, 26 October. http://www.findarticles.com/cf_dls/m1282/1998_Oct_26/53093903/p1/article.jhtml?term Access: November 2006

Parker, Alan. 1999. Angela’s Ashes. Producers Scott Rudin, David Brown and Alan Parker. Hollywood USA: Paramount Pictures.

Pettitt, Lance. 2000. Screening Ireland: Film and television representation. Manchester: Manchester University Press.

Phelan, Eugene. 2000. "Richard Harris stands up for his native city in local radio interview”. RLO. Limerick, 20 January. http://www.limerick.com/angelasashes/controversy7.html Access: November 2006

Richards, Jeffrey. 1997. Films and British National Identity. Manchester: Manchester University Press.

Saah, Jim. 1990-2000. “There once was a man from Limerick...an interview with author Frank McCourt.' UNo MAS Magazine. http://www.unomas.com/features/frankmccourt.html Access: 15 Mar. 2004.

Tobin, Matthew and Lisa O’Connor. 1991-2005. 'Patrickswell-Ballybrown History.' The Heritage Project Diocese of Limerick. http://www.limerickdioceseheritage.org/Patrickswell/hyPatrickswell.htm. Access: February 2007.

‘trooper' The Oxford Dictionary of American Usage and Style. Bryan A. Garner. Oxford University Press, 2000. Oxford Reference Online. Oxford University Press. February 2007.

http://www.oxfordreference.com/views/ENTRY.html?subview=Main\&entry=t26.e2141

Walsh, Maurice. 1933. The Quiet Man. Saturday Evening Post, 11 February. users.orac.net.au. http://users.orac.net.au/ mhumphry/QManSEP.html Access: November 2006 